\title{
Embrapa Network for Brazilian Plant Genetic Resources Conservation
}

\author{
Alfredo Augusto Cunha Alves ${ }^{1}$ and Vânia Cristina Rennó Azevedo ${ }^{2, *}$
}

Brazil is one of the most biodiverse countries on Earth, holding 10\% of the world's vascular plant species. Despite that, Brazilian agriculture is highly dependent on genetic resources originating from other countries. Embrapa (Brazilian Agricultural Research Corporation) is the governmental institution that, since 1973, has been responsible for the introduction and conservation of genetic resources in Brazil. In this article, we report on the experiences that Embrapa has faced over the past 45 years to build and improve a national network for the preservation of plant genetic resources under the coordination of Embrapa Genetic Resources \& Biotechnology (CENARGEN), one of the 42 Embrapa decentralized units. The first network-based model, RENARGEN, initiated in 2003, was followed by the National Platform for Genetic Resources (Platform RG) in 2009; and from 2014 until today Embrapa manages the conservation of genetic resources through Portfolio REGEN, in which the plant component is called Plant Genetic Resources Network (RGV). This network covers activities of enrichment, conservation, characterization, and documentation of genebanks. Embrapa's plant genetic resources are conserved in active genebanks (AGs), in long-term seed bank (Colbase), and in vitro and DNA banks. In situ and on-farm conservation are also handled at Embrapa to complement and reinforce ex situ conservation. The latest survey reveals that Embrapa has 134 AGs with $\sim 150,000$ accessions of 1130 plant species, 123,000 accessions of 735 species within Colbase, 1250 in vitro accessions, and 12,000 DNA samples. At least $65 \%$ of this collection is documented and available to the public in the Embrapa Alelo system, which also handles quarantine, germplasm exchange, and herbarium data. By the end of 2018 , the public Alelo data will be automatically migrated to the Genesys system. In the last 40 years, $\sim 650,000$ accessions have been exchanged by Embrapa, with $70 \%$ of them imported from other countries.

Keywords: active genebank, seed collection, germplasm exchange, ex situ conservation, genebank database

\section{Introduction}

$\mathrm{B}$ RAZIL IS ONE OF THE MOST BIODIVERSE countries on Earth. Its advantageous location (between $5^{\circ} \mathrm{N}$ and $33^{\circ} \mathrm{S}$ and between $35^{\circ} \mathrm{E}$ and $74^{\circ} \mathrm{W}$ ) and its large continental dimension (it is the largest country in the southern hemisphere and the fifth largest in the world in total area) may be the geographic attributes that provide Brazil with the following characteristics:

- Wide climate diversity, with tropical (predominant) and subtropical regions, and derivations of these climates;

- Six vegetation biomes: Amazônia (Amazon Rainforest), Cerrado (Central Savanna), Caatinga (Thorny Forest), Atlantic Forest, Pampas, and Pantanal (Wetlands) ${ }^{1}$;
- Brazil has 33,161 species of vascular plants, which represents $\sim 25 \%$ of the Americas and $10 \%$ of the world plant diversity ${ }^{2}$;

- Brazil is the main center of origin of the new species of vascular plants identified in the last three decades ${ }^{3}$;

- $30 \%$ of Brazilian territory is arable land.

- The largest fresh water reserves on the planet $(8 \%$ of the world volume).

Several Brazilian native species are used as human food, of which we highlight cassava (Manihot esculenta), pineapple (Ananas comosus), peanuts (Arachis hypogaea), cocoa (Theobroma cacao), cashew (Anacardium occidentale), cupuassu (Theobroma grandiflorum), passion fruit (Passiflora edulis), Brazil nuts (Bertholletia excelsa), guaraná

\footnotetext{
${ }^{1}$ Embrapa Cassava \& Fruits (CNPMF), Cruz das Almas, Brazil.

${ }^{2}$ Embrapa Genetic Resources \& Biotechnology (CENARGEN), Brasília-DF, Brazil.

*Present address: International Crops Research Institute for the Semi-Arid Tropics (ICRISAT), Patancheru, India.
}

(C) Alves and Azevedo, 2018; Published by Mary Ann Liebert, Inc. This Open Access article is distributed under the terms of the Creative Commons License (http://creativecommons.org/licenses/by/4.0), which permits unrestricted use, distribution, and reproduction in any medium, provided the original work is properly cited. 
(Paullinia cupana), jaboticaba (Plinia cauliflora), and some palms such as assai (Euterpe oleracea), which is today widely consumed all over the country and exported. ${ }^{4}$ In addition, native forage species are predominantly used in the raising of livestock. On the contrary, Brazilian agriculture is highly dependent on genetic resources originating from other countries. The systematic introduction of exotic genetic resources, the ecological diversity, and the development of technologies and new varieties adapted to the different Brazilian biomes resulted in an intense and ample adaptation and expansion of several crops that are today considered, globally, as basic commodities. Today, Brazil stands out as the third largest producer of grains and the third largest exporter of agricultural products in the world, ranking first in the export of coffee, soybean, sugar, orange juice, alcohol, tobacco, beef, and chicken meat. ${ }^{5}$

The Brazilian Agricultural Research System (SNPA), coordinated by Embrapa (Brazilian Agricultural Research Corporation), is made up of public, federal, and state institutions; universities; private companies and foundations that conduct research in different scientific areas and different geographic regions. Embrapa is linked to the Ministry of Agriculture and Food Supply, and has 42 decentralized units (DUs) distributed throughout the country. Since its founding in 1973, Embrapa was designated to promote and facilitate the safe introduction of genetic resources. Embrapa Genetic Resources \& Biotechnology (CENARGEN) was created in 1974 to coordinate the activities of collection, conservation, quarantine, exchange, characterization, evaluation, and documentation of genetic resources in a collaborative way with SNPA partner institutions. ${ }^{4}$ Since then, collections of germplasm have been structured in different DUs, predominantly for plants.

Brazil has achieved important results in agricultural research, with significant progress in the conservation and use of plant genetic resources, especially those related to food production. In this article, we report on the experiences that Embrapa has faced in the construction of a national network for the conservation and use of Brazilian plant genetic resources.

\section{Maintenance and Conservation of Brazilian Plant Genetic Resources}

\section{Background}

The preservation of genetic resources is essential for maintaining the natural genetic variability for use in breeding programs, especially those for food. In Brazil, this need is especially important as the predominant country's food-based crops are of foreign origin. We can mention, for example, that $90 \%$ of all species conserved in Embrapa's plant collections are of exotic species. ${ }^{6}$

Starting in 2003, Embrapa has operated the first networkbased model of management and conservation of genetic resources in a network called National Genetic Resources Network (RENARGEN). Considering the relevance of genetic resources as strategic assets for agricultural development, this model was improved and, in 2009, RENARGEN was replaced by the National Platform for Genetic Resources formed by four big project networks: (1) plant network, (2) animal network, (3) microbial network, and (4) network integration (transverse network). ${ }^{7}$ The first three network projects focused on the conservation of genetic resources, while the fourth project network was composed of three crosscutting project components: curatorship, documentation, and germplasm exchange, which had a strong interaction with the other component projects of the three networks. ${ }^{7}$

From 2012 to 2015, Embrapa established new corporate management instruments called "Portfolios" to organize projects related to strategic themes of national relevance defined directly by the Board of Embrapa. ${ }^{8}$ Of the 20 corporate portfolios approved during this period, the Strategic Management of Genetic Resources for Food, Agriculture and Bio-Industry (REGEN portfolio) was established in $2014 .^{8}$ In this new model, the plant component, now called Plant Genetic Resources Network (RGV), is implementing a new phase following a restructuring of component projects. The activities of collecting wild relatives and native species of importance for agriculture and food are being reinforced, as well as in situ/on-farm conservation actions in support of ex situ conservation. ${ }^{9}$ The organization and documentation of information in the collections is a priority, and the main innovation in the RGV is the implementation of Quality Systems based on international standards, which is being established from the selection of minimum requirements. ${ }^{9}$

RGV is led by the Plant Genetic Resources Curatorship system, which coordinates germplasm banks and plant collections at a strategic level, allowing the planning of midterm (5 years) conservation actions. RGV consists of 20 component projects, of which 11 are dedicated to the conservation activities of genebanks and the other nine are of transversal actions (Fig. 1). RGV is linked to several other Embrapa's portfolios and project arrangements, considering that conserved genetic resources form the basis for several research projects. ${ }^{9}$

Embrapa's RGV is fed by projects with specific activities for enrichment, conservation, characterization, and documentation of the collections, with the purpose of making them available for research, improvement, and food safety. Currently, Embrapa's plant genetic resources are conserved in (1) active genebanks (AGs), (2) long-term seed bank (Colbase), (3) in vitro bank, and (4) DNA bank. ${ }^{10}$ Colbase works as a safety duplicate of the accessions maintained in $\mathrm{AGs}$, to conserve seeds at $-20^{\circ} \mathrm{C}$ for a long period. ${ }^{11}$ Embrapa also develops research and innovation to subsidize and promote in situ and on-farm conservation, both in natural environments and in agroecosystems. ${ }^{12}$

\section{Ex situ conservation}

Ex situ conservation of plant genetic resources refers to the maintenance of germplasm outside their place of origin in the short, medium, or long term. It comprises activities of enrichment through collection and exchange, documentation and proper conservation. Ex situ plant conservation at Embrapa works on germplasm acquisition through collection expeditions, exchange with institutions in Brazil and abroad, documentation, and development/improvement of methods related to ex situ conservation. The main aim is to do research on the establishment and improvement of methodologies used for ex situ collection and conservation of plant genetic resources, to ensure the physical, physiological, and genetic integrity of the collections, and also to provide the information associated with them. ${ }^{13}$ 
FIG. 1. Scheme of the structure and management of the Embrapa Plant Genetic Resources Network.

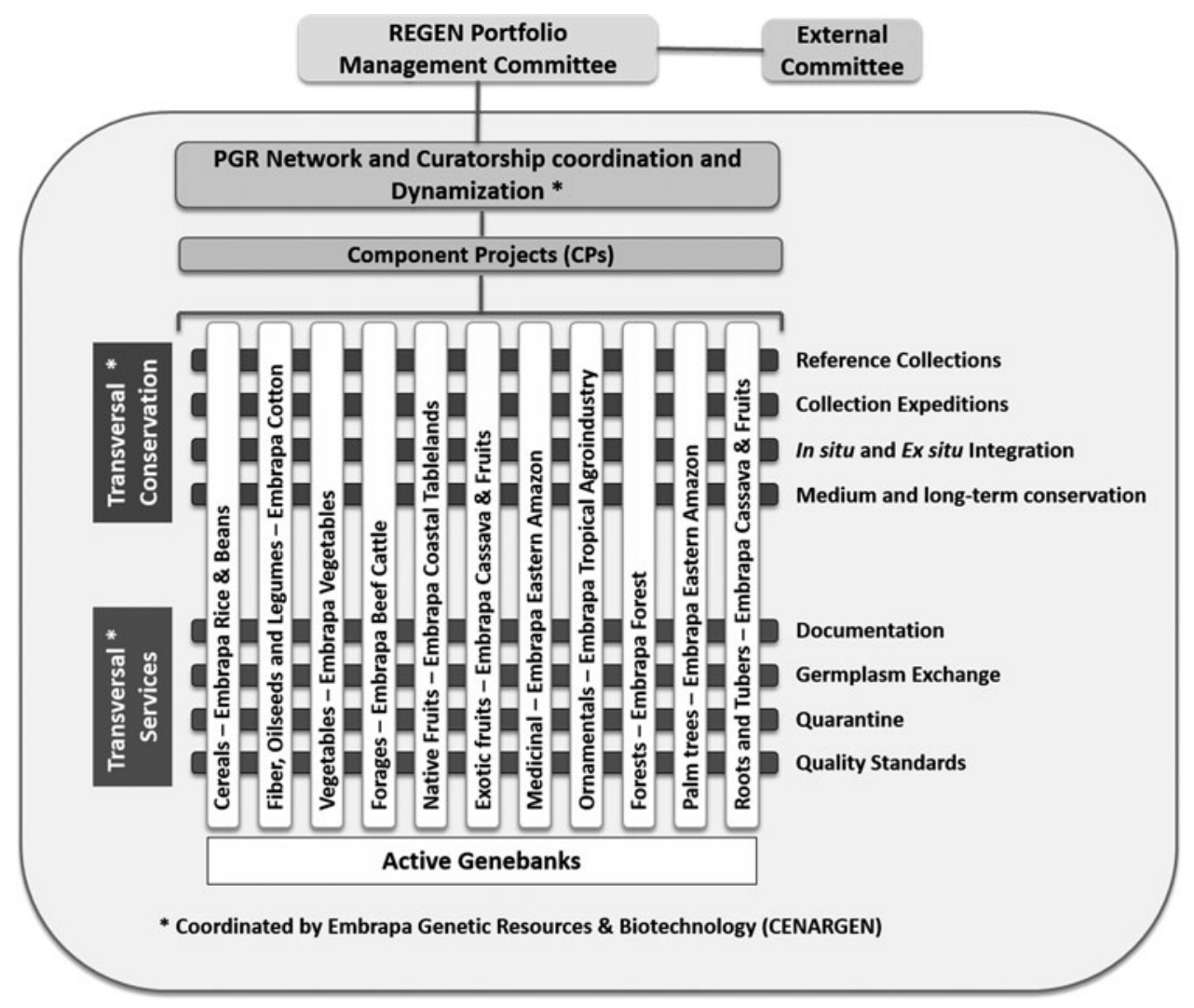

The AGs of Embrapa's RGV are organized in groups of (1) Cereals and Pseudocereals; (2) Oilseeds, Fibrous, and Leguminous; (3) Vegetables and Condiments; (4) Forages; (5) Fruits; (6) Medicinal, Aromatic, Dyes, and Insecticides; (7) Ornamental; (8) Forestry and Palm Trees; (9) Industrial; and (10) Roots and Tubers. ${ }^{10}$ The most recent published global survey carried out by Embrapa reports $\sim 150,000$ accessions of 470 genera and 1130 species (native and exotic) conserved in 134 AGs; 123,000 ac- cessions of 620 genera and 735 species in the Colbase; 1250 accessions of 24 genera and 63 species in the in vitro bank; and 12,000 accessions of 16 genera and 21 species in the DNA bank ${ }^{10}$ (Table 1), involving $\sim 300$ researchers from the different Embrapa units and $\sim 100$ partner institutions. These germplasm collections are strategically distributed in different Brazilian regions and biomes (Fig. 2), in 29 Embrapa's centers, including Embrapa Genetic Resources and Biotechnology, where Colbase is being preserved in the

Table 1. Numbers of Active Genebanks, Genera, Species, and Accessions Conserved in the Embrapa’s Plant Genetic Resources Network

\begin{tabular}{|c|c|c|c|c|c|c|}
\hline \multirow[b]{2}{*}{ Genebank group } & \multicolumn{5}{|c|}{ No. of } & \multirow{2}{*}{$\begin{array}{c}\text { No. of banks } \\
\text { under FAO treaty* }\end{array}$} \\
\hline & Genebanks & Genera & Species & Accessions & Institutions & \\
\hline Cereals and Pseudocereals & 12 & 16 & 88 & 59,408 & 5 & 10 \\
\hline Oilseeds, Fibrous, and Leguminous & 21 & 21 & 169 & 48,323 & 9 & 10 \\
\hline Vegetables and Condiments & 18 & 42 & 72 & 10,878 & 3 & 1 \\
\hline Forages & 14 & 108 & 195 & 9284 & 11 & 2 \\
\hline Fruits & 46 & 74 & 236 & 8693 & 14 & 5 \\
\hline Medicinal, Aromatic, Dyes, and Insecticides & 15 & 86 & 103 & 4108 & 7 & 0 \\
\hline Ornamental & 5 & 90 & 153 & 512 & 4 & 0 \\
\hline Forestry and Palm Trees & 12 & 24 & 56 & 3359 & 6 & 0 \\
\hline Industrial & 8 & 8 & 19 & 2631 & 5 & 0 \\
\hline Roots and Tubers & 10 & 3 & 38 & 5232 & 7 & 9 \\
\hline All active genebanks & 161 & 472 & 1129 & 15,2428 & 29 & 37 \\
\hline Long-term seed bank (Colbase) & 1 & 623 & 735 & 12,3261 & 1 & $*$ \\
\hline In Vitro Bank & 1 & 24 & 63 & 1258 & 1 & $*$ \\
\hline DNA Bank & 1 & 16 & 21 & 12,000 & 1 & $*$ \\
\hline
\end{tabular}

Data from Azevedo and Bustamante. ${ }^{10}$

*Species listed in Annex 1 of the FAO treaty, which are covered by the Multilateral System. Since Brazil is a signatory to the treaty, the accessions of these species must be available via Standard Material Transfer Agreement (SMTA). 


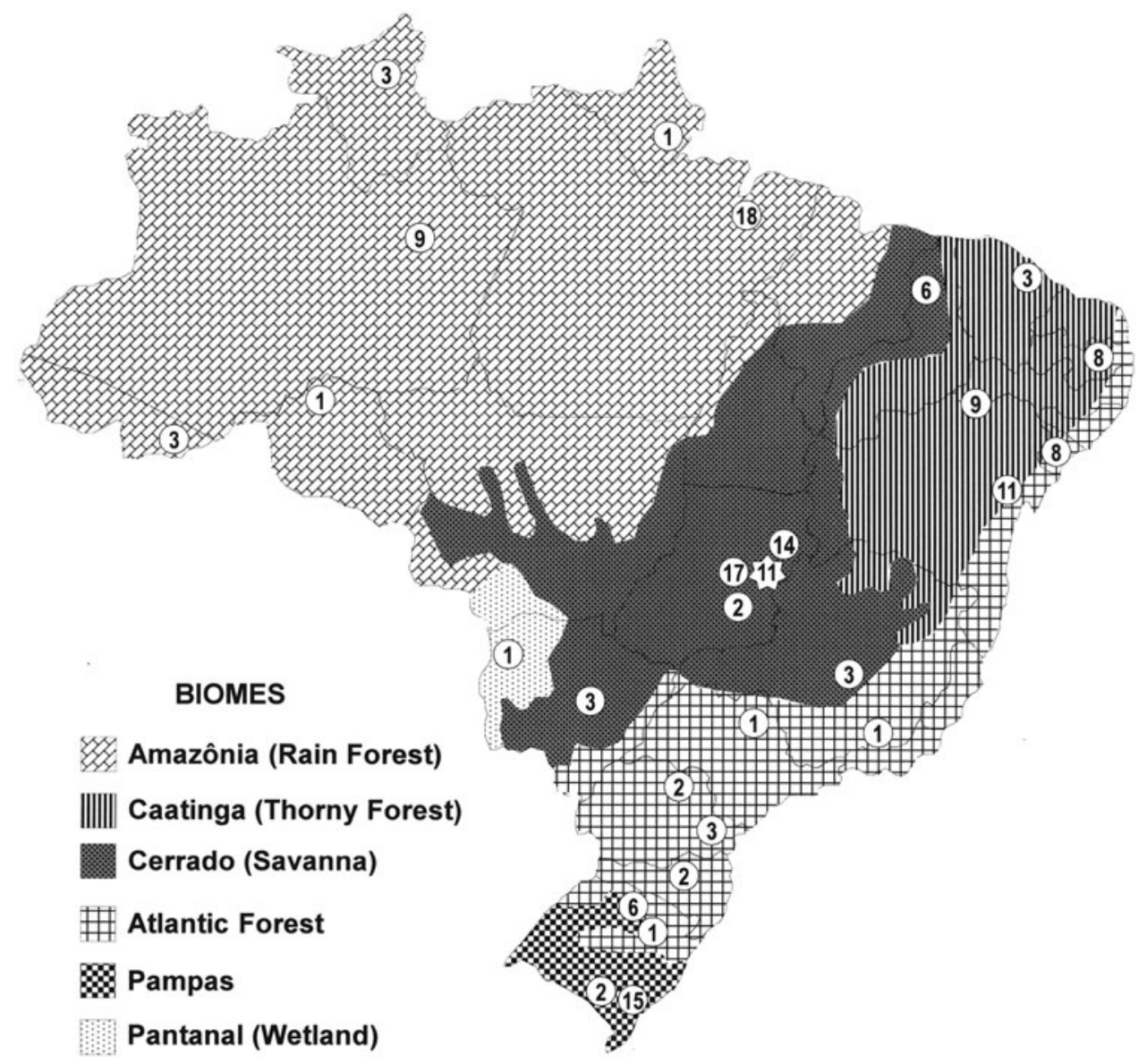

FIG. 2. Distribution of AGs by Brazilian States and Biomes. The values within circles are the numbers of AGs located in 29 of Embrapa's decentralized units. The star in the center of the map represents Embrapa Genetic Resources and Biotechnology (CENARGEN) where the Seed Base Collection (Colbase) and in vitro and DNA banks are preserved at BGen. AGs, active genebanks; BGen, Genetic Bank of Embrapa. Data from Azevedo and Bustamante. ${ }^{10}$ new facility of the Genetic Bank of Embrapa (BGen), in Brasília-DF. It is estimated that at least 240 genebanks are maintained in the other SNPA institutions, ${ }^{14}$ such as Agência Goiana de Assistência Técnica, Extensão Rural, e Pesquisa Agropecuária (EMATER); Empresa de Pesquisa Agropecuária de Minas Gerais (EPAMIG); Empresa de Pesquisa Agropecuária do Estado do Rio de Janeiro (PESAGRO); Empresa de Pesquisa Agropecuária e Extensão Rural de Santa Catarina (EPAGRI); Empresa Mato-grossense de Pesquisa, Assistência e Extensão Rural (EMPAER); Fundação Estadual de Pesquisa Agropecuária (FEPAGRO); Instituto Agronômico de Campinas (IAC); Instituto Agronômico de Pernambuco (IPA); Instituto Agronômico do Paraná (IAPAR); Instituto Nacional de Pesquisa da Amazônia (INPA); Universidade de Campinas (UNICAMP); and Universidade Federal Rural do Rio de Janeiro (UFRRJ).

The DUs that house the largest number of AGs are, in general, ecoregional centers that operate in regions that embrace large biomes such as Embrapa Eastern Amazon (with 18 AGs) in the State of Pará (North Region), Embrapa Temperate Agriculture (15) in the State of Rio Grande do Sul (Southern Region), and Embrapa Cerrados (14) in the State of Goiás (Central-West Region). On the contrary, some Commodities Centers, which work with a large number of crops, are also responsible for maintaining many AGs, such as Embrapa Vegetables (17 AGs) in Brasília-DF (Central-West Region) and Embrapa Cassava \& Fruits (11) in Bahia (Northeast Region) (Fig. 2).

The biggest collections are rice $(27,050$ accessions), soybean $(18,024)$, beans $(16,447)$, wheat $(15,118)$, and sorghum
(7215). Some other collections are very small, such as some native fruits, coconut (36 accessions), and strawberry (20 accessions). It is important to highlight that those collections are maintained in the field or in greenhouses, and the focus is to conserve the genetic diversity of each accession. So, in some cases, there are $>150$ plants of each accession in the field, as in the case of coconut.

\section{Embrapa's Genetic Bank}

BGen, located at CENARGEN, in Brasília-DF, and inaugurated in April 2014, is a two-level building with a total area of $>2000 \mathrm{~m}^{2}$, with modern and safe facilities to preserve, in the medium- and long-term, basic germplasm collections of plant and animal and backup of microorganism collections from Embrapa and partner institutions ${ }^{15}$ (Fig. 3). Plant germplasm is conserved in the form of seeds in cold chambers at $-20^{\circ} \mathrm{C}$, or in the form of vegetative structures by tissue culture or cryopreservation. BGen has laboratories, chambers for seed and in vitro plants conservation, cryopreservation tanks, and ultra-low temperature freezers for DNA banks. The facility for seed conservation is the largest in Latin America with the capacity to store 750,000 seed samples. ${ }^{15}$

The long-term seed storage capacity of the genebank ensures that all Embrapa's AGs can be duplicated in this structure. In vitro conservation and cryopreservation are performed on demand and for species for which protocols have already been developed. Researches to develop new protocols are always in progress. Also, species for which 
FIG. 3. Infrastructure of Embrapa's Genetic Bank, inaugurated in 2014 at CENARGEN, Brasília-DF. (A) building; (B) seed cold chamber; (C) in vitro conservation room; and (D) cryopreservation facilities. Photographs A and B: Melo ${ }^{15,17}$; Photographs C and D: Brazil Agency EBC. ${ }^{18}$
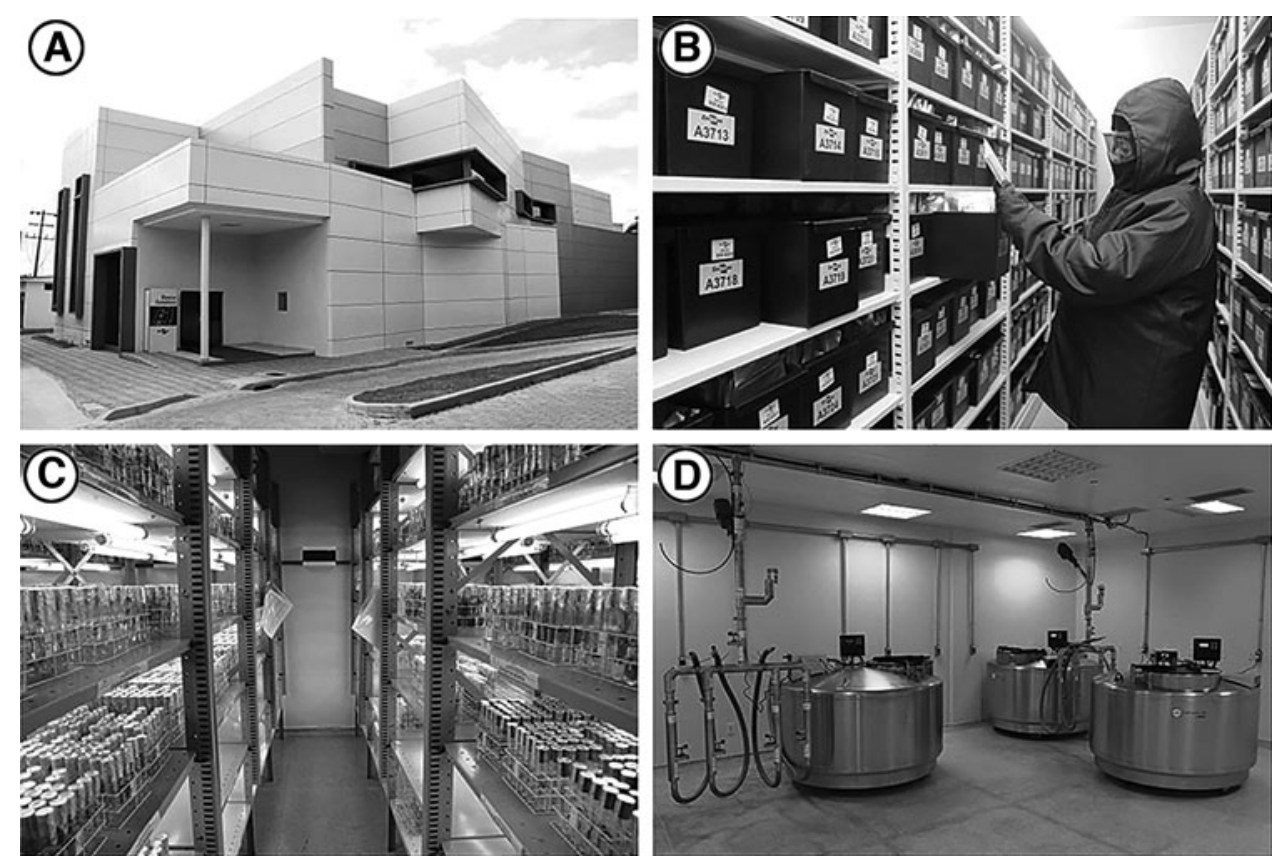

seed conservation is not feasible are prioritized. DNA conservation is also done on demand. This demand may come from ongoing research projects at Embrapa that study population genetics of genetic resource species as well as, and especially, from Colbase seed storage. All material entering the Colbase seed storage has the germination test performed. At least 10 plants of each accession are sent for DNA conservation

One of the objectives of BGen is to house collections of plants, animals, and microorganisms maintained by partner institutions in Brazil and in other countries, such as the backup of the in vitro potato collection of International Potato Center (CIP). ${ }^{16}$ From 2014 to 2016, the complete CIP's collection with 4391 accessions was safety duplicated from Peru to BGen, Brasília (back box security copy). ${ }^{16}$ It is the world's most valuable potato collection in terms of genetic diversity, containing both wild and cultivated varieties.

\section{In situ and on-farm conservation}

In situ and on-farm conservation is essential in conserving genetic resources and complements ex situ conservation. It covers the conservation, management, and restoration of species populations and their associated ecosystems, ensuring the evolution of species over time, in response to changing environmental conditions and the maintenance of agrobiodiversity. Embrapa develops research and innovation to promote conservation, both in natural environments and in agroecosystems, conducting biological inventories and geographic analysis for conservation planning; evaluation and development of management techniques for the sustainable use of biodiversity; ecological restoration in degraded landscapes; analysis and promotion of conservation of genetic resources by local communities and farmers. ${ }^{19}$ These studies subsidize actions and public policies for conservation, aiming not only the maintenance of species and their habitats but also of the human communities and their ways of life. ${ }^{12,19}$
In the case of in situ conservation, important advances were made to create and establish conservation units (CUs) to protect natural areas that are threatened to disappear, such as large areas of forest in the Amazon biome. Furthermore, other important government initiatives, such as research conducted to indicate priority areas for in situ management and the prospecting of native species with potential for sustainable use, have arisen from the ratification by Brazil of the Convention on Biological Diversity in 1994. ${ }^{4}$ To achieve these objectives, the National System of Nature Conservation Units (SNUC) was established in 2000, coordinated by the Ministry of the Environment (MMA), which has promoted the creation and management of CUs at the municipal, state, and federal levels, allowing an overview of the natural areas to be preserved. ${ }^{20}$ In addition, SNUC has been establishing mechanisms that regulate the participation of the society in the management of CUs, enhancing the relationship between the State, citizens, and the environment.

The SNUC is the set of CUs that differ in two broad groups according to the form of protection and permitted uses: (1) those that need greater care due to their fragility and particularities (CU of Full Protection), and (2) those that can be used sustainably (CU of Sustainable Use). ${ }^{21}$ Internationally, protected areas (PAs) are designated as lands for both CUs and traditional populations, such as indigenous lands (ILs). ${ }^{22}$ From the union of these two categories in Brazil, there are a total of 2471 units (1871 CUs + 600 ILs) covering an area equivalent to $30.2 \%$ of the Brazilian territory $^{22}$ (Fig. 4). The relative distribution of PAs in the 26 Brazilian States shows that the percentage of PAs varies greatly from 71 at Amapás State (North) to 0.9 at Paraíba (Northeast). Table 2 shows that Amazonia is the biome with the highest occupation of PAs (51\%), whereas Pampas is the one with the lowest occupation $(3 \%){ }^{22}$ According to the International Union for Conservation of Nature (IUCN), the nine countries with an area of $>2.5$ million $\mathrm{km}^{2}$ devote, on average, $10 \%$ of their territories to PAs; and Brazil is the 


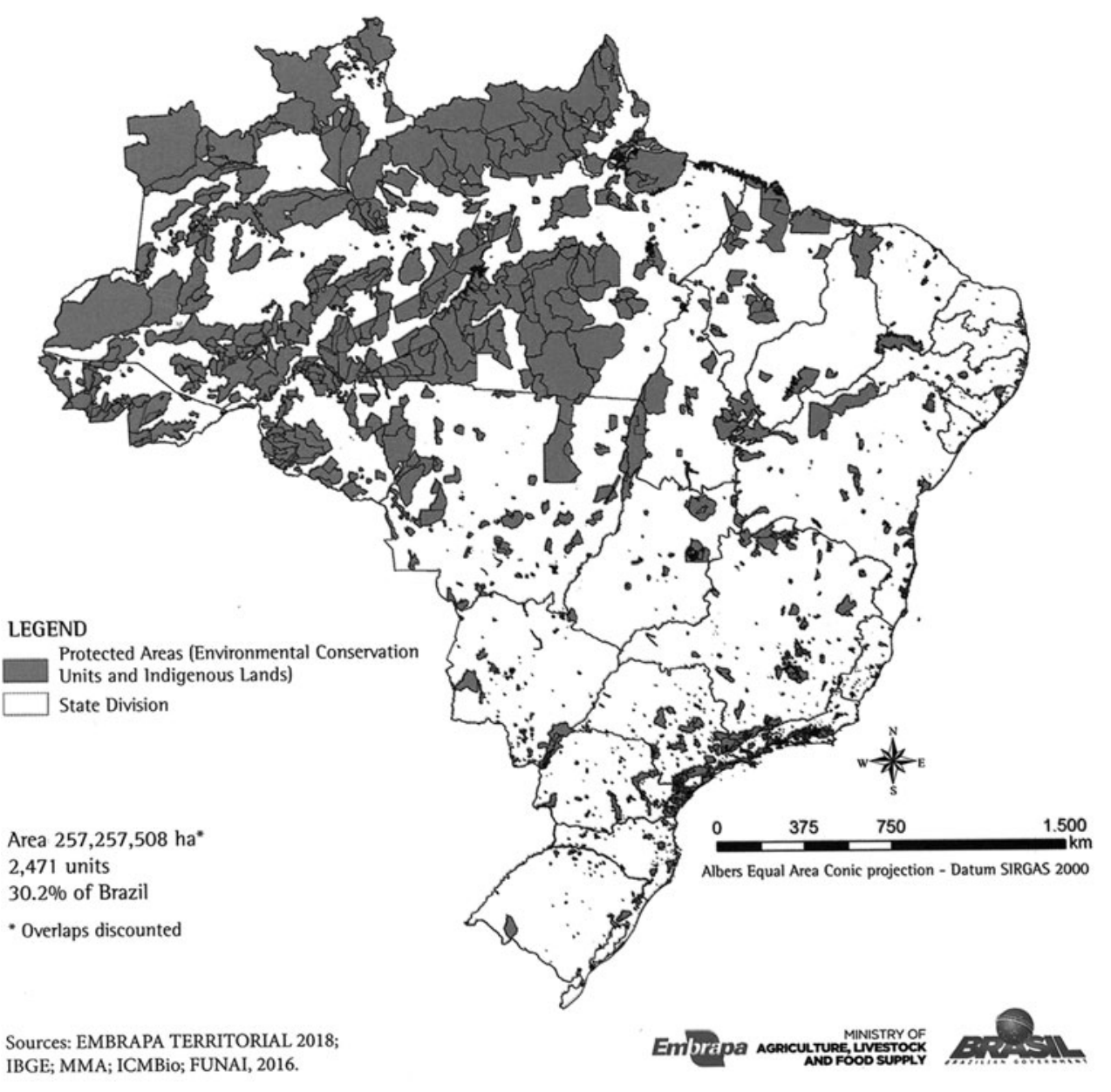

FIG. 4. Distribution of legally protected areas in Brazil, including conservation units and indigenous lands. Source: Miranda. ${ }^{22}$

world champion in environmental protection (Fig. 5). In addition, PAs in Brazil cover areas with great economic potential, which is not the case in most other countries, where they cover bad and desert areas. ${ }^{22}$

To complement in situ conservation, the RGV has two component projects, one to promote the interface between in situ and ex situ conservation strategies, and the other to support collection expeditions to get cultivated species, wild species, and neglected species, in areas prone to any kind of

Table 2. Absolute and Relative Distribution of Protected Areas in the Six Main Brazilian Biomes

\begin{tabular}{lrrr}
\hline Biome & Area (ha) & $\begin{array}{c}\text { Protected } \\
\text { areas (ha) } \\
\text { (CUs }+ \text { ILs) }\end{array}$ & $\begin{array}{r}\text { \% of } \\
\text { protected } \\
\text { areas }\end{array}$ \\
\hline $\begin{array}{lrr}\text { Amazônia } \\
\quad \text { Rain Forest) }\end{array}$ & $418,245,755$ & $212,115,240$ & 50.7 \\
Cerrado (Savanna) & $203,938,059$ & $24,961,235$ & 12.2 \\
Atlantic Forest & $110,613,570$ & $10,020,980$ & 9.1 \\
Caatinga & $82,652,523$ & $6,499,874$ & 7.9 \\
$\quad$ (Thorny Forest) & & & \\
Pantanal (Wetland) & $15,131,294$ & 762,120 & 5.0 \\
Pampas & $17,776,394$ & 506,755 & 2.9 \\
Brazil & $848,357,596$ & $254,866,204$ & 30.0 \\
\hline
\end{tabular}

Values calculated without overlapping. Data from Miranda. ${ }^{22}$ CUs, conservation units; ILs, indigenous lands. risk or in areas considered GAPs in the genebanks, whose diversity is not yet represented in ex situ collections. ${ }^{9}$

\section{Germplasm exchange}

The basic purpose of the plant germplasm exchange system is to promote the import, export, and internal transit of plant propagation material for agricultural research in a safe manner. The introduction of germplasm in Brazil is a dynamic process that aims to obtain more productive varieties resistant to pests and adapted to the soil and climatic conditions of the country. CENARGEN coordinates the exchange of plant germplasm in harmony and cooperation with the Ministry of Agriculture, Livestock and Food Supply (MAPA). ${ }^{23}$

CENARGEN has been exchanging and quarantining imported germplasm since $1976 .{ }^{24}$ By December 2014, a total of 660,139 accessions were exchanged, of which 482,713 were imports, 67,871 exports, and 97,558 domestic exchanges $^{25-27}$ (Table 3). Therefore, $\sim 17,000$ accessions per year were exchanged in this period, the great majority of which refers to imports. The most exchanged crops during this period were corn, wheat, rice, vegetables, soybeans, and beans. International institutions that have sent more germplasm to Brazil include the International Maize and Wheat Improvement Center (CIMMYT, Mexico), the International Center for Tropical Agriculture (CIAT, Colombia); the United States Department of Agriculture (USDA), the CIP 
FIG. 5. - Percentage of protected areas in countries with $>2.5$ million $\mathrm{km}^{2}$ Data from Miranda. 22

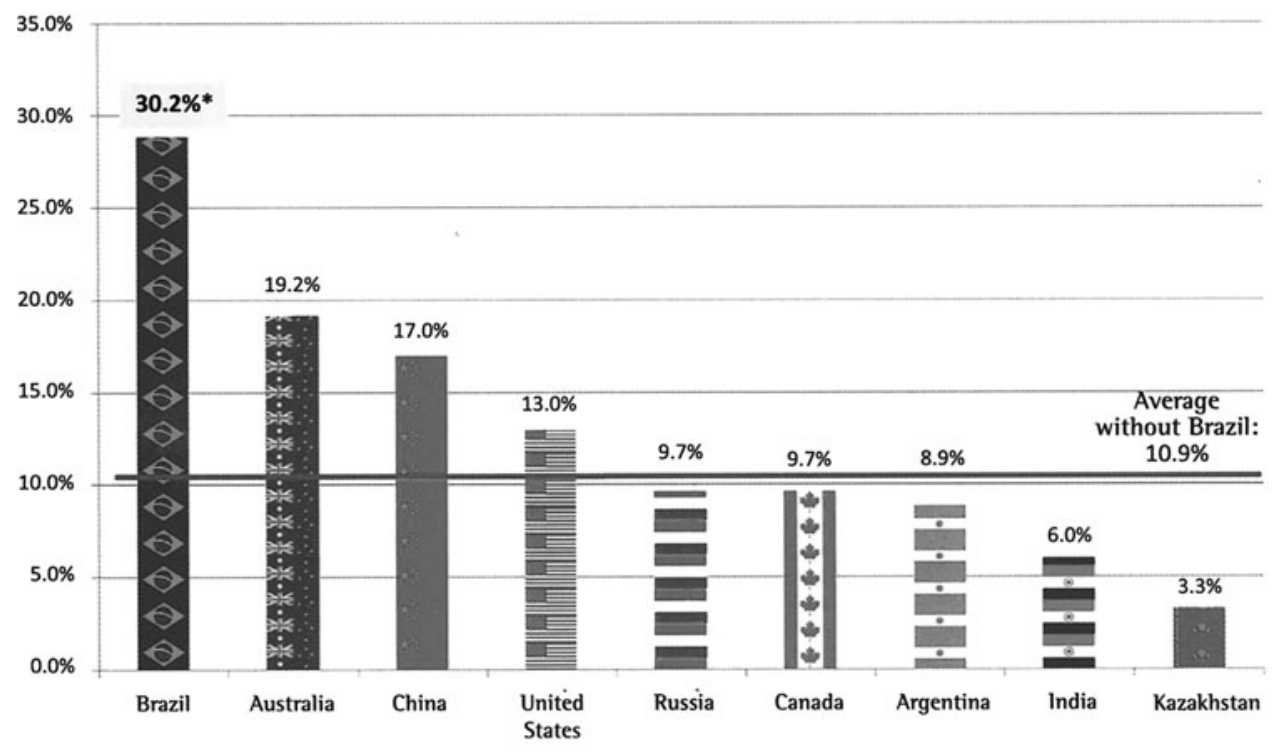

Sources: Protected Planet - UNEP/IUCN/WCPA (2016); EMBRAPA TERRITORIAL, 2018.

* Brazilian official data, not yet considered by the Protected Planet database.

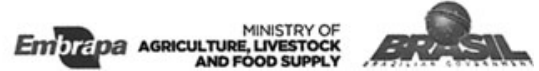

(Peru), the International Rice Research Institute (IRRI, Philippines), and the Commonwealth Scientific and Industrial Research Organization (CSIRO, Australia). The countries that received the most germplasm from Brazil in descending order were United States, Haiti, Peru, France, and Colombia. In Brazil, the institutions that received the greatest quantities of germplasm from abroad were Embrapa (several centers), the Agronomic Institute of Paraná (IAPAR), the Agricultural Research and Rural Extension Company of Santa Catarina (EPAGRI), the Universidade Estadual Paulista (UNESP), and the School of Agriculture "Luis de Queiroz" (ESALQ). ${ }^{4,24-27}$

Brazil is a megadiverse country and, although it is one of the most biodiverse countries in the world, Brazilian agriculture is very dependent on exotic plant genetic resources. Therefore, the exchange and more properly the importation of germplasm have shown to be quite efficient in the enrichment of the genebanks and in the supply of raw material to the plant breeding programs. In this context, almost a half million accessions have been imported

TABle 3. Number OF ACCESSIONS EXCHANGED BY EMBRAPA/CENARGEN FROM 1976 TO 2014

\begin{tabular}{lcccr}
\hline Period & Import & Export & Internal transit & Total \\
\hline $1976-1979$ & 11,338 & 4706 & 8720 & 24,764 \\
$1980-1984$ & 52,360 & 8786 & 16,297 & 77,443 \\
$1985-1989$ & 53,598 & 15,558 & 16,967 & 86,123 \\
$1990-1994$ & 61,844 & 12,912 & 9159 & 83,915 \\
$1995-1999$ & 84,078 & 7949 & 10,448 & 102,475 \\
$2000-2004$ & 90,831 & 2021 & 10,079 & 102,931 \\
$2005-2009$ & 94,830 & 9271 & 9994 & 127,001 \\
$2010-2014$ & 33,834 & 6668 & 15,894 & 55,487 \\
Total & 482,713 & 67,871 & 97,558 & 660,139 \\
\hline
\end{tabular}

Sources: Marques and Marinho, ${ }^{25}$ Ferreira and Silva, ${ }^{26}$ and Visualization of component project. ${ }^{27}$ from other countries, supplying both the various centers of Embrapa and other scientific institutions and universities in Brazil. ${ }^{26}$

Although several species native to Brazil are used as human food, most of them are fruits, nuts, or tubers and roots. Brazil is mainly dependent on exotic germplasm for food. Nevertheless, native materials such as groundnut, cashew, cassava, and pineapple are of interest to other countries. However, the export of Brazil germplasm is very low. This can be explained by very restrictive Brazilian laws. The law number $13,123 / 2015$, currently in force, ${ }^{28}$ defines genetic resources as the genetic information of plants, animals, and microbial species, or any other species, including substances originating from the metabolism of these living organisms. This strict regulation also does not allow the definitive transfer of native genetic resources to other countries or international centers. This makes clear the difficulties faced when negotiating the material exchange agreements. It is also important to highlight that exotic material can easily be exchanged if not considered adapted (when a species forms spontaneous populations and acquired distinctive characteristics in this population) or when considered a landrace. Furthermore, all research with native species must be registered in the National System for $\mathrm{Ge}$ netic Heritage (SisGen) ${ }^{29}$ before any publication or before the development of any commercial product arising from the use of native genetic material. Decree number 8,772/2016, in what concerns this registration, requires that the origin of the genetic heritage found under in situ conditions be informed, even if obtained from ex situ or in silico sources. Therefore, the Law and Decree that regulate access and benefit sharing in Brazil have already recognized access to dematerialized genetic resources in its framework, although this discussion is still ongoing in international level. Thus, the regulation of Law 13,123 provides that to submit a sequence to any database, a Standard Material Transfer Agreement (SMTA) with the database must be signed. Also, 
research utilizing genetic information obtained in silico must register the use of this information at SisGen if the research results are in any publication or product. ${ }^{30}$

\section{Embrapa's Databases on Plant Genetic Resources}

\section{Background}

In the late 1980s, Embrapa/CENARGEN started the development of the Genetic Resources Information System (SIRG), which had a centralized database format with decentralized maintenance and access. ${ }^{31}$ Due to limitations to expand computer equipment, the system was restricted to CENARGEN, preventing its full implementation. In 1996, SIRG underwent a reengineering work, incorporating modern information technologies, used at the time, by USDA's Germplasm Resources Information Network (GRIN), resulting in the development of the Brazilian Genetic Resources Information System (SIBRARGEN), designed to establish and maintain a centralized database on genetic resources of plant, animals, and microorganisms, and making it available through the Internet for searching the following databases: Taxonomy, Passport, Exchange, Quarantine, ex situ Conservation, Collection, Characterization, Evaluation and Use of Germplasm, Curatorship and Germplasm Banks. ${ }^{31}$ The SIBRAGEN homepage was designed with web tools (HTML and JSP) using Embrapa's network infrastructure. In its first phase, the system was implemented within Embrapa. However, other Brazilian institutions, within the SNPA, also have used it. ${ }^{7,31}$

About 8 years using SIBRARGEN, Embrapa decided that it should be technically evaluated to adapt to future needs, both to increase user satisfaction and to improve system performance by incorporating up-to-date Web technologies. At that time, Brazil had been selected by Food and Agriculture Organization (FAO) of the United Nations to join the group of countries that would test the integration of national genetic resources information systems through a multilateral system under development by FAO. ${ }^{7}$ This was done to meet the demand for germplasm exchange based on the MultiCrop Passport Data (MCPD-FAO) in the framework of the International Treaty on Plant Genetic Resources for Food and Agriculture (FAO Treaty). In this pilot test, SIBRARGEN made adjustments to comply MCPD standards and made available passport data of the cassava genebanks. Another important aspect considered in the framework of the system update was the integration of SIBRAGEN Plant Module into Global GRIN (Germplasm Resources Information Network), developed by the USDA in cooperation with Biodiversity International and the Global Crop Diversity Trust. ${ }^{7}$

For at least three decades, Embrapa used the SIBRARGEN as the main database for all genetic resource activities, such as germplasm exchange, quarantine, and long-term conservation, carried out by Embrapa/CENARGEN. Over the years, CENARGEN has ceased to be the main responsible for the collection, conservation, regeneration, and germplasm distribution activities, which are being increasingly carried out by the curators of AGs in the Embrapa's DUs. By now, 29 DUs are involved in Plant Genetic Resources Conservation, from collection up to characterization. With this decentralization, it became necessary to develop a more modern, user-friendly, and accessible online tool that would allow the curators, in any of the DUs, to feed the system with the data related to the bank under their responsibility. CENARGEN, in this new scenario, remains responsible for coordinating the entire conservation system of Embrapa for quarantine, germplasm exchange, and for the long-term collection (Colbase).

\section{Alelo: Embrapa's genetic resources portal}

In view of the need for a new, more modern, and accessible documentation system, Embrapa, in 2011, began to develop the Alelo System. This data platform encompasses all the information related to the conservation of plant, animal, and microbial genetic resources at Embrapa. ${ }^{32}$ The system is designed to document, record, and make data publicly available. Everything about passport data, routine activities and characterization and evaluation can be documented in this system. ${ }^{33}$ It was developed in free software and is available on the Internet (http://alelo.cenargen.embrapa.br). It allows quick and easy access to the general public. It also includes information on quarantine, germplasm exchange, DNA, long-term conservation, in vitro conservation, and the herbarium. ${ }^{34}$ Alelo is populated by the curators and their teams in a decentralized manner, allowing the updating of the Embrapa genetic resources database.

All the information about Embrapa's AGs is being migrated to Alelo platform. It is expected that all the passport data will be available for consultation by the end of 2018 and all information regarding characterization will be available by the end of 2019. Table 4 shows the number of genebanks and accessions that, to date, have already been migrated to the Alelo database. Comparing the data reported in this table with Table 1 (complete inventory), we can see that $70 \%$ of the AGs are already registered in the Alelo, but only $55 \%$ of the accessions were transferred. On the contrary, the upgrade and migration of Colbase are more advanced with $75 \%$ of the accessions transferred to the Alelo.

In recent years, CENARGEN, along with Ministry of Agriculture, Livestock and Food Supply (MAPA), started to share the use of the Alelo platform with other Brazilian research institutes and universities. This can be considered the first step toward organizing and making available all the information regarding the public collections in Brazil. CENARGEN has already signed a membership and responsibility agreement with Rio de Janeiro State Agricultural Research Corporation (Pesagro), Rural Federal University of Rio de Janeiro (UFFRJ), State University of North Fluminense (UENF), State Agricultural Research Foundation (FEPAGRO-RS), and National Institute of Research of the Amazon (INPA). With the agreement, the parties are committed to exchanging confidential and nonconfidential information uploaded, downloaded, and shared through the Alelo portal. ${ }^{34}$

These partnerships are not restricted to national institutions. Teams of curators from Uruguay's National Agricultural Research Institute (INIA) and the Paraguayan Institute of Agrarian Technology (IPTA) have also signed the same agreement, which allows them to perform a range of activities and duties. To work with Embrapa's teams, the curators in partner organizations participate in training on Alelo's reference modules: passport, observation, conservation, and studies for system data validation. ${ }^{34}$ 
Table 4. Active Genebanks and Long-Term Seed Bank (Colbase) Registered in the Embrapa's AleloVegetal Database and Publicly Shared at Alelo's Portal on April 2018

\begin{tabular}{|c|c|c|c|}
\hline \multirow[b]{2}{*}{ Institution } & \multicolumn{2}{|c|}{ No. of } & \multirow[b]{2}{*}{ Genebank names } \\
\hline & Genebanks & Accessions & \\
\hline Carlos Gayer Research Center & 1 & 25 & Kiwi \\
\hline Embrapa Tropical Agroindustry & 3 & 930 & Amaryllidaceae; Cactaceas; Cashew \\
\hline Embrapa Cotton & 6 & 1869 & Carthamus; Castor bean; Cnidosculus; Peanuts; Sesame; Sisal \\
\hline Embrapa Amapá & 3 & 183 & Buriti; Cupuassu; Inajá \\
\hline Embrapa Western Amazon & 6 & 1720 & Cassava; Croton; Cupuassu; Guaraná; Native Fruits; Oil Palm \\
\hline Embrapa Eastern Amazon & 13 & 1183 & $\begin{array}{l}\text { Bacuri; Brazil Nuts; Camu-Camu; Cassava; Cupuassu; Curauá; } \\
\text { Heliconia; Hevea; Ipeca; Jaborandi; Piperacea; Taperebá; } \\
\text { Urucum }\end{array}$ \\
\hline Embrapa Rice \& Beans & 2 & 32,790 & Beans; Rice \\
\hline Embrapa Cerrados & 3 & 285 & Cassava; Macaúba; Passiflora \\
\hline Embrapa Temperate Agriculture & 13 & 2696 & $\begin{array}{l}\text { Azevem; Capsicum; Carrot; Cucurbitaceae; Espinheira-Santa; } \\
\text { Leguminous Forages; Native Fruits; Onion; Ornamentals; } \\
\text { Potato and Wilds; Prunoids; Strawberry; Sweetpotato }\end{array}$ \\
\hline Embrapa Forest & 1 & 578 & Forest species \\
\hline Embrapa Beef Cattle & 2 & 630 & Panicum; Stylosanthes \\
\hline Embrapa Vegetables & 12 & 8721 & $\begin{array}{l}\text { Sweet potato; Capsicum; Cucurbitaceae; Eggplant; Garlic; } \\
\text { Lettuce; Melon; Onion; Pepino; Tomate; Vegetables; Wild } \\
\text { Solanum }\end{array}$ \\
\hline Embrapa Cassava \& Fruits & 7 & 3659 & Acerola; Banana; Bromelias; Cassava; Manihot; Papaya; Pineapple \\
\hline Embrapa Mid-North & 4 & 472 & Babassu; Cajuí; Cowpea; Mango \\
\hline Embrapa Maize \& Sorghum & 3 & 4513 & Maize; Millet; Sorghum \\
\hline Embrapa Pantanal & 1 & 55 & Native Forages \\
\hline Embrapa Southeast Livestock & 1 & 392 & Paspalum \\
\hline Embrapa Southern Livestock & 2 & 542 & Leguminous Forages; South Forages \\
\hline $\begin{array}{l}\text { Embrapa Genetic Resources } \\
\text { and Biotechnology }\end{array}$ & 3 & 828 & Arachis; Cultivars; Fava \\
\hline Embrapa Roraima & 1 & 66 & Orchids \\
\hline Embrapa Semiarid & 7 & 692 & $\begin{array}{l}\text { Amburana; Cenchrus; Grape; Macroptilium; Manihot; Onion; } \\
\text { Spondias }\end{array}$ \\
\hline Embrapa Soybean & 2 & 265 & Pupunha; Sunflower \\
\hline Embrapa Coastal Tablelands & 4 & 581 & Coconut; Desmanthus; Jenipapo; Sugarcane \\
\hline Embrapa Wheat & 6 & 17,403 & Barley; Canola; Oat; Rey; Triticale; Wheat \\
\hline $\begin{array}{l}\text { Amazon Research } \\
\text { National Institute }\end{array}$ & 4 & 769 & Camu-Camu; Cupuassu; Pupunha; Vegetables \\
\hline $\begin{array}{l}\text { State University of } \\
\text { "Norte Fluminense", }\end{array}$ & 1 & 408 & Capsicum \\
\hline All active genebanks & 111 & 82,255 & \\
\hline Long-term seed bank (Colbase) & 1 & 92,895 & 222 Seed banks (grouped by species or genus) \\
\hline
\end{tabular}

Source: http://alelo.cenargen.embrapa.br/

\section{Compatibility of Alelo with global databases}

A cooperation agreement signed between Embrapa and the Global Crop Diversity Trust will enable the automatic migration of public data on plant genetic resources generated by Embrapa to the information system Genesys (https:// www.genesys-pgr.org), a global information portal on genetic resources, which currently houses genebanks data from $\sim 200$ countries, covering $\sim 11$ million records, including passport, collection, characterization, and evaluation. Since Genesys data can be migrated to GRIN Global, the Alelo is compatible with GRIN Global. The main objective is to comply with the requirements of the International Treaty on Plant Genetic Resources for Food and Agriculture (ITPGRFA), ratified by Brazil in 2006. ${ }^{33}$

Embrapa's IT team has developed a tool that allows the automatic migration of information from the Alelo to the global portal. The data to be shared are those updated and validated by the curators of the Actice Genebanks and/or work collections and already made available to the public. In addition to facilitating compliance with ITPGRFA, automatic migration will facilitate the work of the teams involved, which often have to report the same data to different institutions, generating rework. The first stage of this automatic migration will take place in April 2018, and will be held for Genesys and WIEWS-FAO databases (Personal communication, Gilberto Hiragi, 2018).

\section{Herbarium of Embrapa}

Embrapa's Herbarium, located at CENARGEN, was established in 1976, and is registered in the Index Herbariorum (http://sweetgum.nybg.org/science/ih/) with the code CEN. In March 2005, it was accredited as a Faithful Custodian by the Genetic Patrimony Management Council of the Brazilian Ministry of Environment (CGEN/ MMA). Since 1985, it has been made available online. (http://plantwall.cenargen.embrapa.br/elcen2web/elc2html/ 
elc2banco01.asp), and in 2014 its collection is available in the Virtual Herbarium of Flora and Fungi-INCT (http://inct .florabrasil.net/).

CEN Herbarium and its Plant Systematics Laboratory aim to study and record species of Brazilian flora and local flora, carry out expeditions to collect germplasm and support ex situ and in situ conservation actions. Currently, it has $\sim 108,000$ exsiccates and is one of the most representative in Brazil for the Cerrado biome. It also houses growing collections of native plants and wild relatives of Caatinga and Amazon, as well as species of economic interest, including forage grasses and legumes, cassava, peanuts, pineapples, yams, oleaginous, ornamental, medicinal, forest and wild relatives of cultivated plants. Since 2017, data and images from this herbarium are available in the Global Biodiversity Information Facility (GBIF) (https://www.gbif.org), which is the largest online database on global biodiversity. ${ }^{35}$

\section{Final Considerations}

Over the last 40 years, Embrapa has developed a large and complex system for the conservation of plant genetic resources. As a National Agricultural Research Institution, it took over the responsibility of conserving $>140$ different crops and wild relatives, allowing Embrapa to access a very rich source of resources that culminated in the development of hundreds of projects and consequently hundreds of cultivars, patents, and processes. They all had and still have conserved genetic resources as the basis of the research.

\section{Author Disclosure Statement}

No conflicting financial interests exist.

\section{References}

1. Perez EL, Mariante AS. Introduction to the country and the agricultural sector. In: Mariante AS, Sampaio MJA, Inglis MCV (eds). The State of Brazil's Plant Genetic Resources: Second National Report: Conservation and Sustainable Utilization for Food and Agriculture. Brasília, DF: Embrapa Technological Information: Embrapa Genetic Resources and Biotechnology; 2009: 25-38.

2. Ulloa Ulloa C. An integrated assessment of the vascular plants species of the Americas. Science 2017;358:1614-1617.

3. Royal Botanic Gardens. The State of the World's Plants Report 2016. Kew, United Kingdom: The Board of Trustees of the Royal Botanic Gardens; 2016: 84.

4. Mariante AS, Sampaio MJA, Inglis MCV (eds). The State of Brazil's Plant Genetic Resources: Second National Report: Conservation and Sustainable Utilization for Food and Agriculture. Brasília, DF: Embrapa Technological Information: Embrapa Genetic Resources and Biotechnology; 2009: 236.

5. FAOSTAT. Data Crops. Rome: FAO (Food and Agriculture Organization of the United Nations); 2018. http://www .fao.org/faostat/en/\#data/QC (accessed March 21, 2008).

6. Bustamante PG, Ferreira FR. Accessibility and exchange of plant germplasm by Embrapa. Crop Breed Appl Biotechnol 2011;1:95-98.

7. Mariante AS, Pezzini TG. National programs, training, agreements and conventions applicable to plant genetic resources. In: Mariante AS, Sampaio MJA, Inglis MCV (eds). The State of Brazil's Plant Genetic Resources: Second National Report: Conservation and Sustainable Utili- zation for Food and Agriculture. Brasília, DF: Embrapa Technological Information: Embrapa Genetic Resources and Biotechnology; 2009: 133-149.

8. Portfolios: Strategic management of genetic resources for food, agriculture and bioindustry-Regen. Brasília, DF: Embrapa; 2018. https://www.embrapa.br/en/pesquisa-e-desenvol vimento/portfolios (accessed April 3, 2018).

9. Visualization of the management plan of the network project: Plant genetic resources network of the REGEN Portfolio. Brasília, DF: Embrapa; 2015. https://sistemas.sede .embrapa.br/ideare/pages/relatorios/formatoimpressaosub missao/FormatoImpressaoSubmissao.jsf (accessed March 31, 2018).

10. Azevedo VCR, Bustamante PG. Genetic Resources Preserved at Embrapa: Updated History and Inventory. Brasília, DF: Embrapa; 2014: 184.

11. Pádua JG. Medium and long-term collections. In: Azevedo VCR, Bustamante PG (eds). Genetic Resources Preserved at Embrapa: Updated History and Inventory. Brasília, DF: Embrapa; 2014: 173-178.

12. Simon MF. Manual of germplasm curators - plant: in situ conservation. Brasília, DF: Embrapa Recursos Genéticos e Biotecnologia; 2010: 14. (Documentos, 322).

13. Ex situ conservation of plant genetic resources. Brasília, DF: Embrapa; 2018. https://www.embrapa.br/en/recursosgeneticos-e-biotecnologia/gp/ex-situ (accessed April 11, 2018).

14. José SCBR. Manual of germplasm curators - plant: ex situ conservation (Colbase - Seeds). Brasília, DF: Embrapa Recursos Genéticos e Biotecnologia; 2010: 13. (Documentos, 317).

15. Melo CB. Multimedia: Image bank, Genetic Bank of Embrapa Genetic Resources and Biotechnology. Brasília, DF: Embrapa; 2017. https://www.embrapa.br/busca-de-imagens/-/ midia/4175001/banco-genetico-da-embrapa-recursos-geneticose-biotecnologia (accessed March 22, 2018).

16. Diniz F. Embrapa receives final collection of potato from Peru: backup is complete. Brasília-DF: Embrapa; 2016. https://www.embrapa.br/en/trigo/busca-de-noticias/-/noticia/ 11323911/embrapa-recebe-ultima-remessa-da-colecao-debatata-do-peru-copia-de-seguranca-esta-completa (accessed March 26, 2018).

17. Melo CB. Multimedia: Image bank, Genetic Bank of Embrapa Genetic Resources and Biotechnology. II. Brasília, DF: Embrapa; 2017. https://www.embrapa.br/en/recursosgeneticos-e-biotecnologia/busca-de-imagens/-/midia/4179001/ banco-genetico-da-embrapa-recursos-geneticos-e-biotec nologia-ii (accessed March 22, 2018).

18. Brazil Agency - EBC. News in detail: Embrapa inaugurates largest genebank in Latin America. Campos, RJ: Prefeitura de Campos; 2014. https://www.campos.rj.gov.br/exibirNoticia .php?id_noticia=24984 (accessed March 22, 2018).

19. In situ conservation and management of genetic resources. Brasília, DF: Embrapa; 2018. https://www.embrapa.br/en/ recursos-geneticos-e-biotecnologia/gp/in-situ (accessed April 11, 2018).

20. Corandin L, Silva AJR. The environment, biodiversity and the promotion of the use of its genetic resources. In: Veiga RFA, Queiróz MA. (eds). Plant Genetic Resources: the basis of sustainable agriculture in Brazil. Brasília, DF: Sociedade Brasileira de Recursos Genéticos; 2015: 419-431.

21. Leuzinger MD. Brief overview of Brazilian environmental legislation. In: Cases MO (Org.). Management of conservation units: sharing a training experience. Brasília, DF: WWF-Brasil; 2012: 57-72. 
22. Miranda E. Shades of green: sustainable agriculture in Brazil. São Paulo: Metalivros; 2018: 220.

23. Ferreira FR. Manual of germplasm curators - plant: procedures related to the exchange of plant germplasm and interfaces with the system of curatorships. Brasília, DF: Embrapa Recursos Genéticos e Biotecnologia; 2010: 16. (Documentos, 310).

24. Camargo CP, Carlos M, Dores ER, et al. Exchange of plant germplasm at Embrapa Genetic Resources and Biotechnology. Brasília, DF: Embrapa Recursos Genéticos e Biotecnologia; 2006: 17. (Documentos, 190).

25. Marques ASA, Marinho VLA. Movement of plant germplasm in Brazil - Exchange and Quarantine. In: NASS LL (ed). Plant Genetic Resources. Brasília, DF: Embrapa Recursos Genéticos e Biotecnologia; 2007: 145-168.

26. Ferreira FR, Silva Neto SP. Successful examples of plant introduction and acclimatization in Brazil. In: Veiga RFA, Queiróz MA (eds). Plant Genetic Resources: the basis of sustainable agriculture in Brazil. Brasília, DF: Sociedade Brasileira de Recursos Genéticos; 2015: 148-159.

27. Visualization of component project: PC19. Plant germplasm exchange. Brasília, DF: Embrapa; 2015. https://sistemas .sede.embrapa.br/ideare/pages/relatorios/consultageral projetos/ConsultaGeralProjetos.jsf (accessed March 31, 2018).

28. BRAZIL. Law number 13,123, May 20, 2015. Access to genetic heritage. Brasília, DF; 2015. http://www.planalto .gov.br/ccivil_03/_ato2015-2018/2015/lei/113123.htm (accessed April 4, 2018).

29. BRAZIL. Decree number 8,772, May 11, 2016. Access to genetic heritage. Brasília, DF; 2016. http://www.planalto .gov.br/ccivil_03/_ato2015-2018/2016/decreto/D8772.htm (accessed April 4, 2018).

30. Ministry of the Environment. SisGen User Manual. Brasília, DF; 2017. https://sisgen.gov.br/download/Manual_Sis Gen.pdf (accessed April 4, 2018).
31. Costa IRS, Cajueiro EVM, Monteiro JS, et al. Documentation and informatization of genetic resources. In: Nass LL (ed). Plant Genetic Resources. Brasília, DF: Embrapa Recursos Genéticos e Biotecnologia; 2007: 605-626.

32. Technology Solutions: Alelo. Brasília, DF: Embrapa; 2013. https://www.embrapa.br/pt/recursos-geneticos-e-biotecnologia/ busca-de-solucoes-tecnologicas/-/produto-servico/1731/alelo (accessed April 2, 2018).

33. Diniz F. Embrapa database on plant species used in food and agriculture will be shared on a global basis. Brasília, DF: Embrapa; 2017. https://www.embrapa.br/en/ busca-de-noticias/-/noticia/20323424/base-de-dados-daembrapa-sobre-especies-vegetais-usadas-na-alimentacaoe-agricultura-sera-compartilhada-em-base-global (accessed April 13, 2018).

34. Rodrigues D. Alelo Portal strengthens national and international institutions' databases. Brasília, DF: Embrapa; 2017. https://www.embrapa.br/en/web/portal/busca-de-noticias/-/ noticia/24247116/alelo-portal-strengthens-national-andinternational-institutions-databases (accessed April 11, 2018).

35. Diniz F. Data from the Embrapa Herbarium will be made available in the Global Biodiversity Information System (GBIF). Brasília, DF: Embrapa; 2016. https://www.embrapa .br/recursos-geneticos-e-biotecnologia/busca-de-noticias/-/ noticia/17688550/dados-do-herbario-da-embrapa-seraodisponibilizados-no-sistema-global-de-informacao-sobre-abiodiversidade-gbif (accessed March 15, 2018).

Address correspondence to: Alfredo Augusto Cunha Alves, PhD Embrapa Cassava \& Fruits (CNPMF) Cruz das Almas 44380-000 Brazil

E-mail: alfredo.alves@embrapa.br 